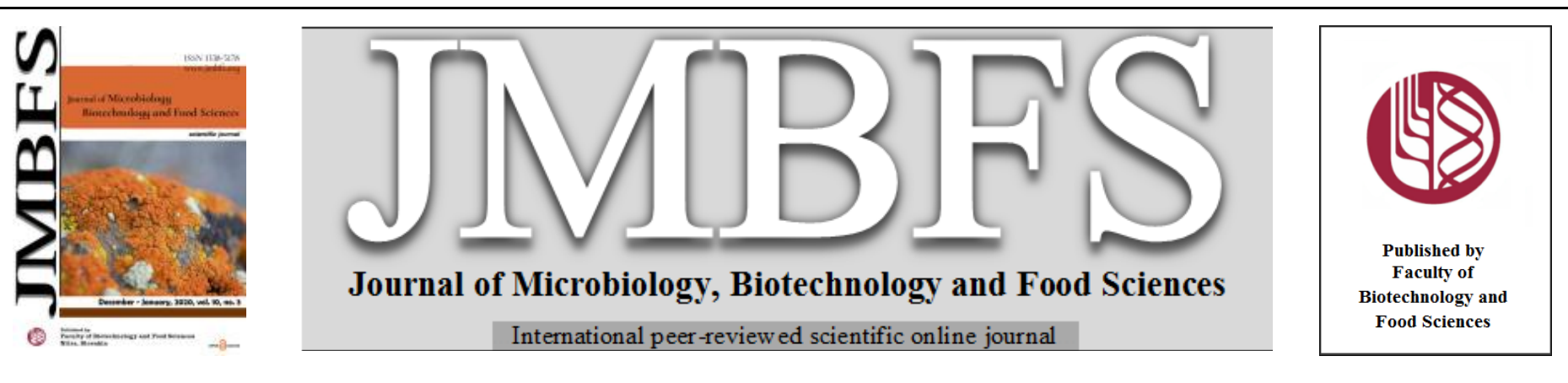

\title{
UTILIZATION OF TANNIC ACID BY BACTERIA IN TROPICAL AQUATIC AND SOIL ENVIRONMENTS
}

\author{
Emmanuel Olumuyiwa ${ }^{* 1,2}$, Olukayode Amund ${ }^{1}$, Matthew Ilori ${ }^{1}$, Stefan Schmidt ${ }^{2}$
}

\author{
Address(es): \\ ${ }^{1}$ Department of Microbiology, University of Lagos, Akoka, Lagos, Nigeria, Phone: (+234) 7039336614. \\ ${ }^{2}$ Discipline of Microbiology, School of Life Sciences, University of KwaZulu-Natal, Pietermaritzburg, 3201, South Africa.
}

*Corresponding author: kaybaba3@gmail.com

doi: 10.15414/jmbfs.2020.10.3.335-343

\section{ARTICLE INFO}

Received 16. 4. 2020

Revised 13.6. 2020

Accepted 3. 7. 2020

Published 1. 12. 2020

Regular article

OPEN $\partial_{\text {ACCESS }}$

\begin{abstract}
Two bacterial strains designated as EO1 and EO2, were isolated by selective culture enrichment from Lagos lagoon water and mangrove soil samples. They were subsequently identified based on morphological and physiological characteristics as well as 16S rRNA gene sequence analysis as Klebsiella pneumoniae strain EO1 and Pantoea cypripedii strain EO2 with accession numbers KX355800 and KX355801. Microbial growth assessment was performed in triplicates under aerobic batch conditions. The two isolates were capable of utilizing tannic acid, gallic acid, glucose, succinate, benzoic acid, and protocatechuic acid as sole carbon sources. Growth experiments along with enzymatic studies indicated that the organisms hydrolyzed tannic acid through gallic acid and pyrogallol as metabolic intermediates. The organisms have potential for the elimination of polyphenolic pollutants such as gallotannins associated with wood residues in Nigerian estuarine environments.
\end{abstract}

\section{INTRODUCTION}

Mostly in the developing countries, the problem of pollution of water and soil from the tannin-rich systems is a serious environmental risk (Mohammed, 2016). Tannins, a group of naturally occurring polyphenols, which are widespread and copious in seeds, fruits, and leaves, and also in timber wood and bark of trees. They are the fourth most abundant plant constituents after cellulose, hemicellulose, and lignins; while tannin and lignin are the most abundant and widely distributed phenolic polymers of higher plants (Brooker $\boldsymbol{e t}$ al., 1999; Mingshu et al., 2006). They widely occur in common foodstuffs such as tea, strawberry, grape, mango, walnut, and cashew nut (Clifford and Scalbert, 2000). Due to the fact that they play no direct role in plant metabolism, they are regarded as secondary metabolic compounds of plants. On the basis of their structural characteristics, tannins are divided into four major groups namely, gallotannins, ellagitannins, complex tannins and condensed tannins (Mingshu $\boldsymbol{e t}$ al., 2006). Generally known gallotannins are gallic acid esters of glucose, such as tannic acid (TA), which appears in the form of a yellowish-white or pale brown powder usually obtained from twig galls of Rhus semialata.

The inhibitory or toxic nutritional effects of tannins found in animals, particularly among the ruminants, results in reduction of feed intake, lowering the nutrient digestibility as well as protein availability (Van Soest, 1994; Lowry et al., 1996). The reason for this fact is that tannins form complexes with protein, starch, and digestive enzymes, consequently reducing the digestibility and nutritional qualities of feeds (Chang et al., 1998; Aguilar and GutierrezSanchez, 2001). Tannins before now has been found toxic to microorganisms and this activity is mostly due to enzyme inhibition and substrate deprivation, action on membranes and metal ion deprivation (Reed, 1995). Despite these antimicrobial properties, many fungi, bacteria, and yeasts are resistant to tannins and have developed various mechanisms and pathways for their degradation in natural habitats (Scalbert, 1991; Mingshu et al., 2006). Pepi et al. (2010) for the first time described the aerobic degradation of gallotannins by an Achromobacter sp.; bacterial strains from Gram positive and Gram negative genera such as Bacillus, Staphylococcus, Klebsiella, Lactobacillus, Streptococcus, Pseudomonas, Pantoea, and Serratia have the ability to catabolize these polyphenolic compounds were also reported (Pepi et al., 2010; Jadhav et al., 2011; Sivashanmugam and Jayaraman, 2011). Bacteria that grow in tannins presence are often regarded tannin-resistant, which is restricted not by species or geographical barriers (Pell et al., 2000).

Tannase (tannin acyl hydrolase, EC 3.1.1.20) catalyzes the hydrolysis of ester and depside linkages in hydrolyzable tannins like tannic acid. The products of hydrolysis are glucose and gallic acid (Lekha and Lonsane, 1997; Mohapatra et al., 2009). Applications of Gallic acid (GA) could be in photography and printing inks, production of the anti-microbial drug trimethoprim, and in the manufacture of propyl gallate, which is used as an antioxidant in fats and oils. Additionally, gallic acid exhibits cytotoxic activity against cancer cells and possesses antibacterial, antiviral, and analgesic properties (Pourrat et al., 1987; Kar et al., 1999; Mondal et al., 2001; Trevino-Cueto et al., 2007; Bajpai and Patil, 2008). Besides gallic acid production, tannase is used extensively in the preparation of beer, wine, instant-tea, and coffee-flavoured soft drinks and as an additive for detannification of food. Tannase, its potential use can also be found in the treatment of wastewater contaminated with polyphenolic compounds such as tannic acids (Seth and Chand, 2000; Belmares et al., 2004; Mukherjee and Banerjee, 2006; Aguilar et al., 2007).

Several studies have shown that contaminated environments harbor a wide range of pollutant-degrading bacteria that play a crucial role in the natural mineralization of pollutants present in the environment (Leahy and Colwell, 1990; Van Hamme et al., 2003). Numerous polyphenolic compounds designated as high production volume chemicals (HPVCs) are frequently encountered constituents of wastewaters that end up in the sea or estuaries, and the disposal of tannin-rich woods results in leaching of tannin into the soil.

The trans-boundary incursion of the water hyacinth (Eichorniea crassipes) into the Lagos lagoon from the neighboring creeks in Benin republic as well as plant litter from the mangrove forest also contributes significant amounts of tannins to the lagoon (Buraimoh et al., 2015).

Consequently, tannins contribute to the aromatic burden of the Lagos lagoon Although the pollutant degrading capabilities of Lagos lagoon and tropical mangrove forest soil bacteria are well known, the catabolism of tannins in the lagoon and the adjoining mangrove forest soil had received somewhat limited attention. Hence, this study was undertaken to bridge the information gap. The isolation of two bacterial isolates that can utilize tannic acid (TA) and gallic acid (GA) aerobically as sole sources of carbon and energy from estuarine and mangrove forest samples from the Lagos lagoon highlights the metabolic versatility of bacteria present in this environment. 


\section{MATERIALS AND METHODS}

\section{Chemicals}

All chemicals used unless stated otherwise, were obtained from Merck (Germany) or Sigma-Aldrich (Germany) and were of the highest purity commercially available.

\section{Collection of water and soil samples}

The Lagos lagoon water samples laden with decomposing sawdust were obtained from a saw mill axis at Oko-Baba, Ebute-Metta, Lagos, Nigeria (Decimal degrees Co-ordinates: N6.4911; E3.3919) and soil samples, black in colour, from the mangrove forest zone located at the University of Lagos, Nigeria (Decimal degrees Co-ordinates: N6.5178; E3.4009). Soil was collected at $10-20 \mathrm{~cm}$ depth from topsoil. All samples were collected into properly labelled sterile glass bottles, transported to the laboratory on ice and processed within $12 \mathrm{~h}$ for the isolation of bacteria.

\section{Enrichment and isolation of tannin-degrading strains}

The selective enrichments were carried out using mineral salts medium (MSM) containing tannic $\left(1 \%\left(\mathrm{~W} \mathrm{v}^{-1}\right)\right)$ or gallic acid $(2.5 \mathrm{mM})$ as the sole source of carbon and energy. One millilitre $(1 \mathrm{ml})$ of lagoon water collected from OkoBaba sawmill axis was aseptically transferred into $100 \mathrm{ml}$ Erlenmeyer flasks containing $30 \mathrm{ml}$ enrichment medium $\left(\mathrm{NaNO}_{3} 3 \mathrm{~g} \mathrm{~L}^{-1} ; \mathrm{KCl} \quad 0.5 \mathrm{~g} \mathrm{~L}^{-1}\right.$ $\mathrm{MgSO}_{4} .7 \mathrm{H}_{2} \mathrm{O} 0.5 \mathrm{~g} \mathrm{~L}^{-1} ; \mathrm{KH}_{2} \mathrm{PO}_{4} 1 \mathrm{~g} \mathrm{~L}^{-1} ; \mathrm{FeSO}_{4} .7 \mathrm{H}_{2} \mathrm{O} 10 \mathrm{mg} \mathrm{L}^{-1}$, adjusted to $\mathrm{pH}$ $6.5 \pm 0.2$ ), with the selected carbon source added aseptically after the medium was sterilized at $121{ }^{\circ} \mathrm{C}$ for 15 minutes. The stock solution of tannic acid $(10 \mathrm{~g} \mathrm{~L}$ ${ }^{1}$ ) was sterile filtrated using MS-Nylon syringe filters (30 mm diameter, $0.22 \mu \mathrm{m}$ pore size, Millipore, USA). Enrichment cultures were incubated at $30{ }^{\circ} \mathrm{C}$ on a benchtop shaking incubator at $150 \mathrm{rpm}$ for $24-48 \mathrm{~h}$. Then $1 \mathrm{ml}$ of enrichment cultures was sub-cultured into $40 \mathrm{ml}$ of fresh sterile medium containing tannic acid or gallic acid for another 24-48 h. The same procedure was used for soil samples except that $1 \mathrm{~g}$ of soil sample was employed. After four rounds of transfer, samples $(100 \mu \mathrm{L})$ from the enrichment cultures were streaked onto solid enrichment medium with either tannic acid or gallic acid as sole carbon source to isolate individual bacterial colonies.

\section{Screening for tannin degraders}

Selected colonies were screened further for tannic acid and gallic acid utilization by using the halo and $\mathrm{FeCl}_{3}$ reaction described by Pinto et al. (2001) and Sariozlu and Kivanc (2009). Strains that exhibited maximum zones of clearance were selected and further characterized microbiologically. Working cultures of isolates were maintained on nutrient agar (NA) slants at $4{ }^{\circ} \mathrm{C}$

\section{Cultural and morphological characteristics of bacterial isolates}

Colony attributes of strains were observed visually on Nutrient agar (NA) plates and mineral salts agar with tannic acid as carbon source after incubation at $30^{\circ} \mathrm{C}$ for 24 - 48 h. Cellular morphologies were analyzed using phase-contrast microscopy (Olympus BH2).

\section{Electron microscopy}

Cell morphologies were further verified by electron microscopy employing a transmission electron microscope (TEM) (Philips, CM120 Biotwin) using formvar-coated copper grids. Cells from an overnight culture grown in nutrient broth were stained with $2 \%$ uranyl acetate (Moxley and Schmidt, 2012).

\section{Biochemical characteristics of bacterial isolates}

Catalase reaction, oxidase test, nitrate reduction, starch hydrolysis, motility, Hydrogen sulfide production, citrate utilization, and sugar fermentation with acid production (MRVP) of isolates were assessed according to Holt et al. (1994).

\section{Amplification of the 16S rRNA gene}

Genomic DNA from isolates was extracted from a single colony grown on nutrient agar using the Jena Bioscience Bacteria DNA Preparation Kit. The purity and concentration of the extracted DNA were evaluated using a Nanodrop (ND 1000) Spectrophotometer (Thermo Scientific, USA). All the samples showed a DNA yield between $200-400 \mathrm{ng}$, with an A260/A280 ratio between $1.68-1.75$.

The PCR based amplification of the 16S rRNA genes of strains EO1 and EO2 was done using the primer pair 27F and 1541R. The PCR reactions were carried out in $25 \mu \mathrm{l}$ reactions containing 1x PCR Master mix (Solis Biodyne), $1.5 \mathrm{mM}$ $\mathrm{MgCl}_{2}, 200 \mu \mathrm{M}$ of each dNTP (Solis Biodyne), $25 \mathrm{pmol}$ of each primer (BIOMERS, Germany), 2 units of Hot FIREPol DNA polymerase (Solis
Biodyne), $2 \mu 1$ of the extracted DNA, with nuclease free sterile distilled water (Solis Biodyne) used to make up the reaction mixture. The parameters for PCRbased amplification were as follows: Thermal cycling was conducted in an Eppendorf Vapo protect thermal cycler (Nexus Series) for an initial denaturation of $95{ }^{\circ} \mathrm{C}$ for 5 minutes, followed by 35 amplification cycles of 30 seconds at 95 ${ }^{\circ} \mathrm{C}$ (denaturation); 1 minute at $61{ }^{\circ} \mathrm{C}$ (an annealing) and 1 minute 30 Seconds at $72{ }^{\circ} \mathrm{C}$ (elongation). This was followed by a final extension step of 10 minutes at $72{ }^{\circ} \mathrm{C}$. The amplification products were separated on $1.5 \%$ agarose gel, and electrophoresis was carried out at $80 \mathrm{~V}$ for 1 hour 30 minutes. DNA bands were visualized by ethidium bromide staining. A molecular weight DNA ladder (100bp, Solis Biodyne) was used.

\section{Analyses of 16S rRNA gene sequences}

The 16S rRNA gene sequences of the two representative isolates selected were sequenced (GATC Biotech., Germany), and the sequences obtained were deposited at GenBank (NCBI) under accession numbers KX355800 and KX355801. Subsequently, these sequences were compared to matching 16S rRNA gene sequences present in GenBank using the Basic Local Alignment Search Tool (BLAST, www.ncbi.nlm.nhi.gov/BLAST/Blast.cgi). MEGA version $\mathrm{X}$ Software (Kumar et al., 2018) was employed to construct phylogenetic trees using the neighbor-joining algorithm (Saitsou and Nei, 1987) with re-sampling for over 500 replicates. The tree topology was verified by using additionally the maximum likelihood algorithm.

\section{Growth studies}

The isolates were routinely grown using the specified minimal salts medium with tannic acid or gallic acid added to a final concentration of $10 \mathrm{~g} \mathrm{~L}^{-1}$ or $2.5 \mathrm{mM}$ Cells were routinely grown for growth experiments in $250 \mathrm{ml}$ Erlenmeyer flasks containing $100 \mathrm{ml}$ of the tannic acid medium (TAM) or gallic acid medium (GAM) and incubated at $30{ }^{\circ} \mathrm{C}$ on a shaking incubator at $150 \mathrm{rpm}$. Cell growth was routinely monitored by measuring the optical density at $600 \mathrm{~nm}$ using a UVVIS spectrophotometer (UV-1800, Shimadzu). In addition, the total cell counts were obtained by light microscopy employing a Helber type bacterial counting chamber. The decrease in tannic acid concentrations over time was initially analyzed using UV-VIS spectroscopy at $600 \mathrm{~nm}$ in cell free medium samples The utilization of these aromatic substrates was analytically verified by Gas Chromatography-Mass Spectrometry (GC-MS). Controls without aromatic compounds (tannic acid or gallic acid) as the utilizable carbon source served to demonstrate that biomass formation was dependent on the productive utilization of this compound, while inoculations with inactive cells (i.e. heat - inactivated cells $\left(80^{\circ} \mathrm{C}, 1 \mathrm{~h}\right)$ served as abiotic controls.

\section{Utilization of tannic acid medium (TAM) and gallic acid medium (GAM)}

TAM and GAM - grown cells of isolates EO1 and EO2 were harvested from 40 $\mathrm{ml}$ culture liquid by centrifugation $((5,000 \mathrm{x} \mathrm{g}, 10 \mathrm{~min})$ and after being suspended in sterile saline solution $(0.85 \%)$, inoculated into $250 \mathrm{ml}$ Erlenmeyer flasks containing $70 \mathrm{ml}$ sterile MSM supplemented with TA $\left(250 \mathrm{mg} \mathrm{L}^{-1}\right)$ and GA (approx. $300 \mathrm{mg} \mathrm{L}^{-1}$ ) respectively. Non-inoculated TAM and GAM flasks served as abiotic controls. Samples were collected $(1 \mathrm{ml})$ sequentially at intervals of $12 \mathrm{~h}$ and the experimental flasks were incubated at $30{ }^{\circ} \mathrm{C}$ on a shaking incubator at $150 \mathrm{rpm}$. Culture and control samples were stored at $-20^{\circ} \mathrm{C}$ prior to intermediate analysis.

\section{Analytical Methods}

\section{Thin Layer Chromatography (TLC)}

Thin layer chromatography was done according to Singh et al. (1999) with slight modifications. Briefly, gallic acid and glucose were estimated in aliquots of the bacterial cultures withdrawn and centrifuged at $8000 \mathrm{x}$ g for 20 minutes at $15{ }^{\circ} \mathrm{C}$ and $10 \mu 1$ of the supernatant samples were spotted on thin layer chromatography plate (F254nm-Merck KGaA, DC Kieselgel, Darmstadt, Germany). A mixture of n-butanol: acetic acid: water (4:1:5) was used as mobile phase and the components on the TLC plate were visualized using UV light and additionally by heating after spraying with ferric chloride $(0.1 \mathrm{~g})$ in $30 \%$ methanol (Mondal et al., 2001).

\section{Gas Chromatography-Mass Spectrometry (GC-MS)}

Metabolites were extracted from cell free culture supernatants with diethyl ether, the ether extracts of the degradation products were dissolved in $0.5 \mathrm{ml}$ of pyridine. The mixture was then silylated by addition of $\mathrm{N}, \mathrm{O}$-bistrimethylsily trifluoroacetamide (BSTFA) and 1\% trimethylchlorosilane (TMCS) for GC-MS analysis. The sample solution $(2 \mu \mathrm{l})$ was injected into a GC-MS system (Shimadzu QP2010 SE Quadrupole MS) (Japan) with an SGA BPX5 bonded phase, fused silica column $(30 \mathrm{~m} \times 0.25 \mathrm{~mm}$ inner diameter, $0.25 \mu \mathrm{m}$ film thickness). The temperature profile for GC operation was isothermal at $80{ }^{\circ} \mathrm{C}$ for 
two minutes, followed by a $5{ }^{\circ} \mathrm{C}$ minute ${ }^{-1}$ temperature gradient to $200{ }^{\circ} \mathrm{C}$ and a $15{ }^{\circ} \mathrm{C}$ minute ${ }^{-1}$ gradient to $280{ }^{\circ} \mathrm{C}$ and isothermal period at $280{ }^{\circ} \mathrm{C}$ for 10 minutes. The MS conditions were electron ionization $(70 \mathrm{eV})$ and scanning rate of 60 scans minute ${ }^{-1}$. The chromatograms were recorded and metabolites were identified by comparison of their retention times and fragmentation patterns with those of authentic samples and using the internal library.

\section{Carbon source assimilation}

The following substrates were tested for utilization by the isolates using the method of Schmidt and Fornagel (1998); benzoate, protocatechuate, $p$ hydroxybenzoate, catechol, tannic acid, gallic acid, gallic acid methyl ester, glucose, resorcinol, 3-methoxybenzoate, succinate, salicylate and tartrate Abilities of the isolates for the consumption of the tested aromatic compounds were further analyzed spectrophotometrically (Chowdhury et al., 2004).

\section{Plate assay for utilization of tannic acid}

The abilities of bacterial isolates to utilize tannic acid as a sole carbon source were verified using semisolid minimal medium agar containing tannic acid $(0.05 \%)$ as sole carbon source and triphenyl tetrazolium chloride $(0.5 \%)$. Equal amounts of log-phase cells of the strains were harvested by centrifugation, washed 2 times using sterile saline, and pellets were resuspended in saline and 20 $\mu 1$ placed at the centre of each plate. The plate was then incubated at $30{ }^{\circ} \mathrm{C}$ for 48-72 h (Chowdhury et al., 2004).

\section{Estimation of residual tannic acid}

Tannic acid was estimated spectrophotometrically (Hagerman and Butler, 1978; Kumar et al., 1999). Cells were grown overnight in minimal medium containing $0.2 \%$ tannic acid. To $1 \mathrm{ml}$ of culture filtrate, $2 \mathrm{ml}$ of bovine serum albumin (BSA) $\left(1 \mathrm{mg} \mathrm{ml}^{-1}\right)$ and $0.17 \mathrm{~mol}^{-1} \mathrm{NaCl}$ in $0.2 \mathrm{M}$ acetate buffer, $\mathrm{pH} 5.0$ was added. After 10 minutes incubation, samples were centrifuged at $2200 \mathrm{~g}$ for 10 minutes. The pellet was washed with acetate buffer and $4 \mathrm{ml}$ of SDS TEA solution ( $1 \%$ sodium dodecyl sulfate, $\mathrm{w} \mathrm{v}^{-1}$ and $5 \%$ triethanolamine, $\left.\mathrm{v} \mathrm{v}^{-1}\right)$ and 1 $\mathrm{ml}$ of $\mathrm{FeCl}_{3}\left(0.01 \mathrm{~mol}^{-1} \mathrm{FeCl}_{3}\right.$ in $\left.0.01 \mathrm{~N} \mathrm{HCl}\right)$ was added. The tubes were then incubated at $30{ }^{\circ} \mathrm{C}$ for 15 minutes and absorbance was recorded at $510 \mathrm{~nm}$ in a spectrophotometer (UV mini-1240, Shimadzu).

\section{Enzyme Assays}

Tannase activities of the isolates were tested following the spectrophotometric and visual reading methods described by Osawa and Walsh (1993).

\section{RESULTS}

Cultural, morphological, biochemical and genotypic characteristics of bacterial isolates

Selective enrichment resulted in the isolation of two bacterial strains designated as EO1 and EO2, which utilized tannic acid as sole source of carbon and energy as evidenced by production of clear zones on tannic acid containing mineral salts medium.

Strain EO1, isolated from lagoon water, was a Gram-negative non spore forming and non-motile isolate, oxidase negative and catalase-positive with cells mostly appearing as rod-shaped (about $1.9 \times 0.8 \mu \mathrm{m}$ ) in the logarithmic phase of growth, frequently occurring in pairs (Figure 1). The organism fermented most of the carbohydrates tested such as arabinose, lactose, sorbitol, and sucrose. The strain was negative in the methyl red test and did not produce $\mathrm{H}_{2} \mathrm{~S}$ but formed acetoin (VP test) and utilized citrate. Strain EO2, isolated from mangrove soil, was Gram negative, produced round, cream-coloured colonies of $2 \mathrm{~mm}$ in diameter on nutrient agar, with motile cells $(1.6 \times 0.6 \mu \mathrm{m})$ showing peritrichous flagella (Figure 2). EO2 was catalase-positive, oxidase-negative, and exhibited fermentative growth on glucose. It produced acid from arabinose, fructose, galactose, glucose, trehalose, and $\mathrm{N}$-acetylglucosamine, while no gas was produced from glucose. It lacked urease, arginine dihydrolase, lysine decarboxylase, and gelatinase, and did not produce $\mathrm{H}_{2} \mathrm{~S}$.

The PCR products obtained for the 16S rRNA genes of strains EO1 and EO2 $(1700 \mathrm{bp})$ are shown in Figure 3. Comparison to sequences deposited in GenBank showed that the partial 16S rRNA gene sequence of strains EO1 and EO2 showed the highest similarities ( $\geq 99 \%$ ) to type strain sequences of Klebsiella pneumoniae subsp. rhinoscleromatis ATCC 13884(T) ACZD01000038 and Pantoea cypripedii LMG 2657(T) MLJI01000002 respectively. These results were confirmed by phylogenetic analyses depicting close relationships between the isolated strains EO1 and $K$. pneumoniae and EO2 and P. cypripedii (Figure 4 and Figure 5).

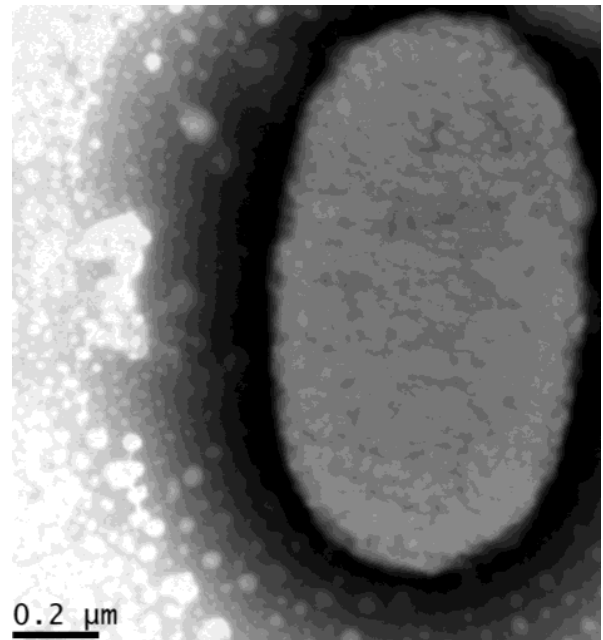

Figure 1 Transmission electron micrograph (TEM) of a typical single cell of Klebsiella pneumoniae strain EO1 from an exponentially growing culture using tannic acid as sole carbon source.

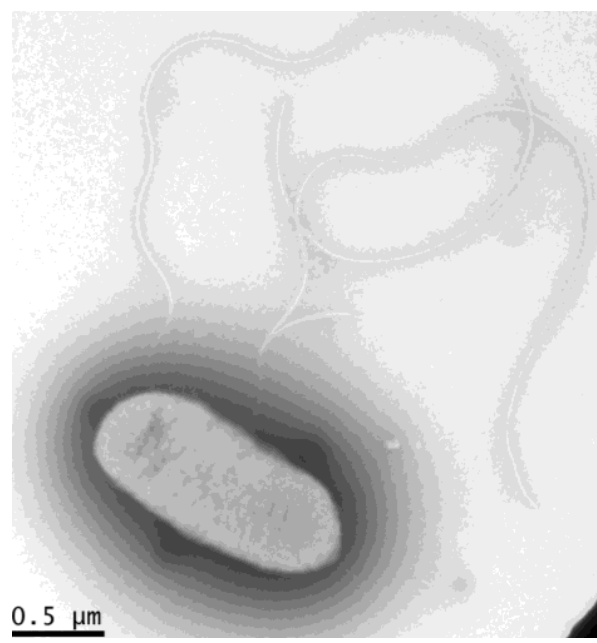

Figure 2 Transmission electron micrograph (TEM) of a typical single cell of Pantoea cypripedii strain EO2 from an exponentially growing culture using tannic acid as sole carbon source.

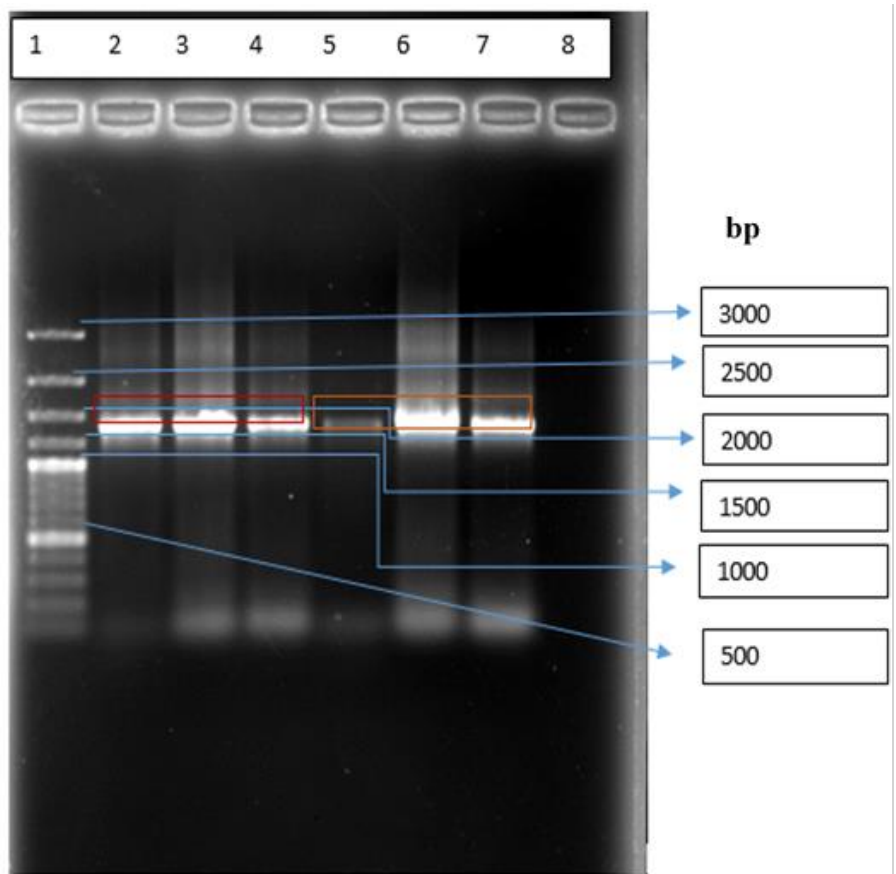

Figure 3 Gel electrophoresis of the amplified 16S rRNA genes of strains EO1 and EO2. Lane1, molecular marker; lane 2-4, EO1; lane 5-7, EO2 and lane 8, control. 


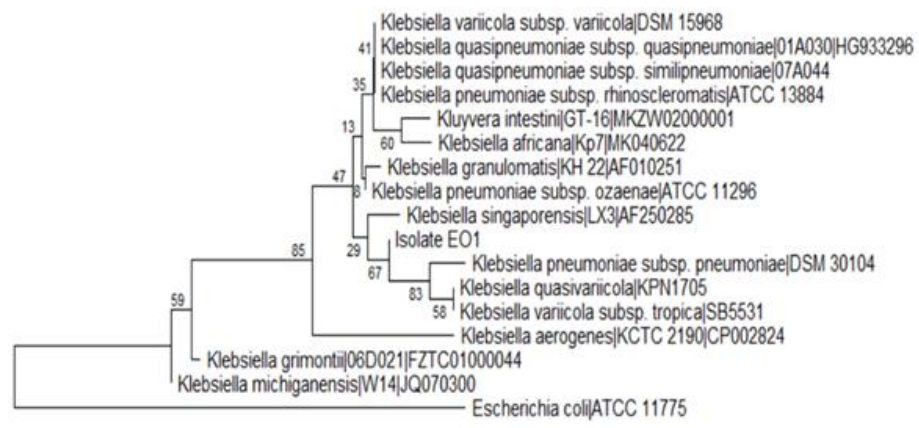

0.01

Figure 4 Phylogenetic tree constructed by the neighbour-joining method based on 16S rRNA gene sequences of strain EO1 and related Klebsiella species retrieved from NCBI GenBank. Bootstrap values are given at branching points. Bar represents 0.01 nucleotide substitutions per nucleotide position. The $16 \mathrm{~S}$ rRNA gene sequence of Escherichia coli was used as an out-group.

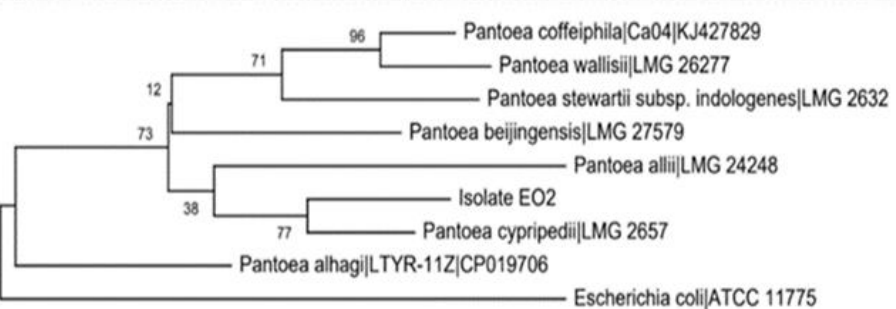

\subsection{1}

Figure 5 Phylogenetic tree constructed by the neighbour-joining method based on 16S rRNA gene sequences of strain EO2 and related Pantoea species. Bootstrap values are given at branching points. Bar represents 0.01 nucleotide substitutions per nucleotide position. The 16S rRNA gene sequence of Escherichia coli was used as an out-group.

\section{Microbial growth}

The abilities of Klebsiella pneumoniae strain EO1 and Pantoea cypripedii strain $\mathrm{EO} 2$ to grow on tannic acid as the only source of carbon and energy were demonstrated by the increase in biomass $\left(\mathrm{OD}_{600}\right)$ and cell numbers over time. In the absence of tannic acid, no growth was detected in cultures. Growth of the bacteria expressed as the increase in optical density at $600 \mathrm{~nm}$ was tightly correlated to the removal of tannic acid from liquid cultures. Abiotic (cell free cultures) and heat inactivated cells (incubated for $1 \mathrm{~h}$ at $80{ }^{\circ} \mathrm{C}$ ) used as controls showed no decrease in tannic acid over time, thus verifying that the loss of tannic acid in cultures was due to microbial metabolism.

The highest biomass yield of strains EO1 and EO2 were obtained at tannic acid concentrations of $5.0 \mathrm{~g} \mathrm{~L}^{-1}$ (Figure 6) and $2.5 \mathrm{~g} \mathrm{~L}^{-1}$ (Figure 7) and $10 \mathrm{mM}$ (Figure 8 ) and $2.5 \mathrm{mM}$ (Figure 9) for TA and GA respectively. This is not unexpected on physicochemical grounds as the half-life for tannins in the aquatic environment is expected to be rather long due to the limited tendency for volatilization. The doubling times of the bacterial strains EO1 and EO2 during the exponential growth phase at $30{ }^{\circ} \mathrm{C}$ were determined as $10 \mathrm{~h}$ and $9 \mathrm{~h}$ (Figure 10 and Figure 11).

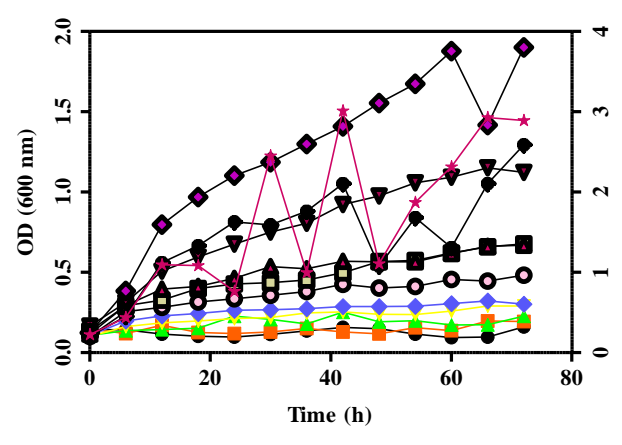

TA Concs. $\left(\mathrm{g} \mathrm{L}^{-1}\right)$

$\rightarrow 0$

- 0.1

$\triangle \mathbf{0 . 2 5}$

TV.5

$\leftarrow 0.75$

- 1

- 1.5

$\triangle 2$

$\rightarrow \quad 2.5$

$\checkmark 5$

$-7.5$

$\star \quad 10$

Figure 6 Growth of Klebsiella pnuemoniae strain EO1 measured as a function of optical density at $600 \mathrm{~nm}$ for $72 \mathrm{~h}$ of incubation at $30^{\circ} \mathrm{C}$ and $150 \mathrm{rpm}$ at different tannic acid concentrations.

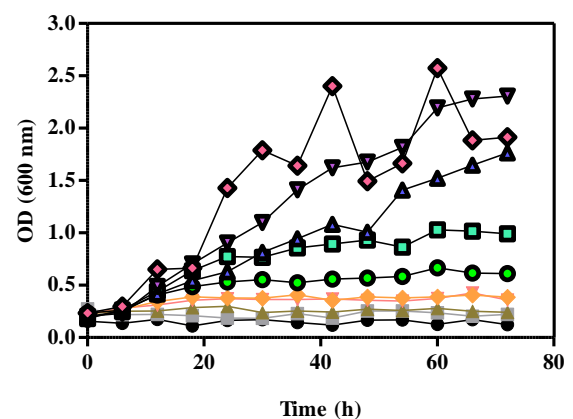

TA Concs. $\left(\mathrm{g} \mathrm{L}^{-1}\right)$

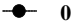

- 0.1

$\longrightarrow \quad 0.25$

$\rightarrow \quad 0.5$

$\rightarrow 0.75$

- 1

$-1.5$

$\triangle 2$

$\rightarrow \quad 2.5$

$\diamond 5$

Figure 7 Growth of Pantoea cypripedii strain EO2 measured as a function of optical density at $600 \mathrm{~nm}$ for $72 \mathrm{~h}$ of incubation at $30^{\circ} \mathrm{C}$ and $150 \mathrm{rpm}$ at different tannic acid concentrations.

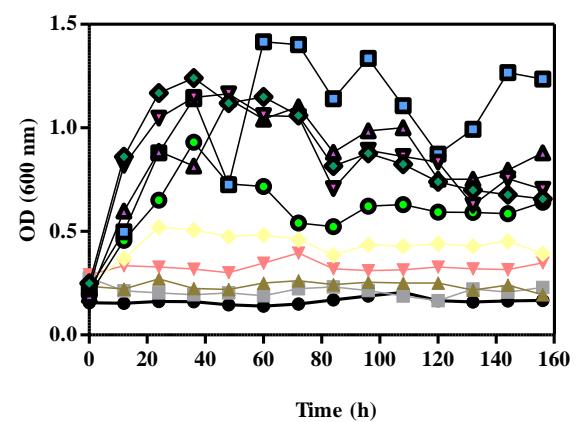

GA Concs. $(\mathrm{mM})$

$\rightarrow 0$

$-0.25$

$\rightarrow \quad 0.5$

$\rightarrow \quad 1$

1.5

- 2.5

- 3.5

$\triangle 5$

$\rightarrow \quad 7.5$

$-10$

Time (h)

Figure 8 Growth of Klebsiella pnuemoniae strain EO1 measured as a function of optical density at $600 \mathrm{~nm}$ over $120 \mathrm{~h}$ of incubation at $30{ }^{\circ} \mathrm{C}$ and $150 \mathrm{rpm}$ at different gallic acid concentrations.

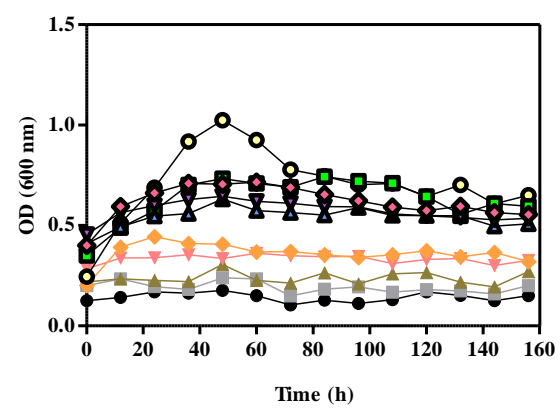

GA Concs. $(\mathrm{mM})$

$-0$

$-0.25$

$\pm 0.5$

$\rightarrow-1$

$\rightarrow 1.5$

- 2.5

- 3.5

$\triangle 5$

$\rightarrow 7.5$

- 10

Figure 9 Growth of Pantoea cypripedii strain EO2 measured as a function of optical density at $600 \mathrm{~nm}$ over $120 \mathrm{~h}$ of incubation at $30{ }^{\circ} \mathrm{C}$ and $150 \mathrm{rpm}$ at different gallic acid concentrations. 


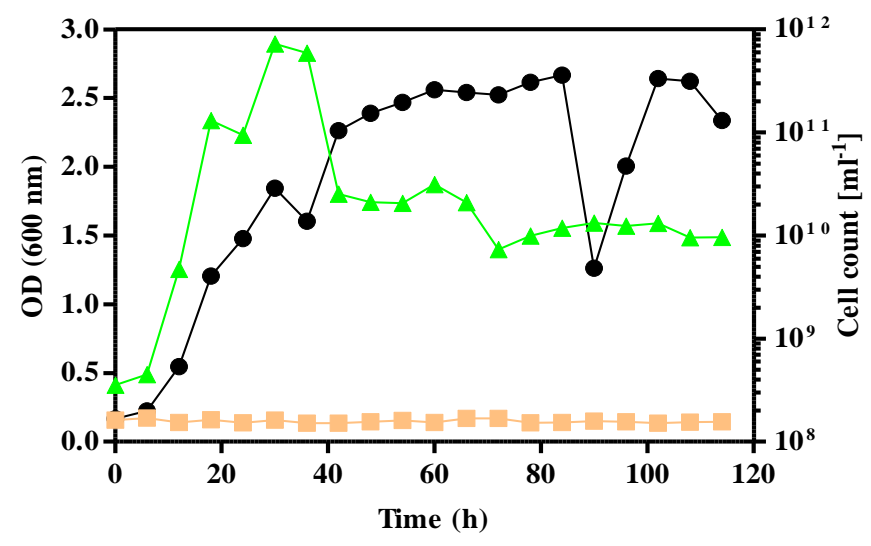

Figure 10 Growth of Klebsiella pneumoniae strain EO1 with $2.5 \mathrm{mM}$ tannic acid as sole source of carbon and energy. Growth parameters $\left(\mathrm{OD}_{600}=\bullet\right.$, cell count $=$ $\Delta$ ) plotted against time together with control in the absence of tannic acid $\left(\mathrm{OD}_{600}\right.$ $=\square)$.

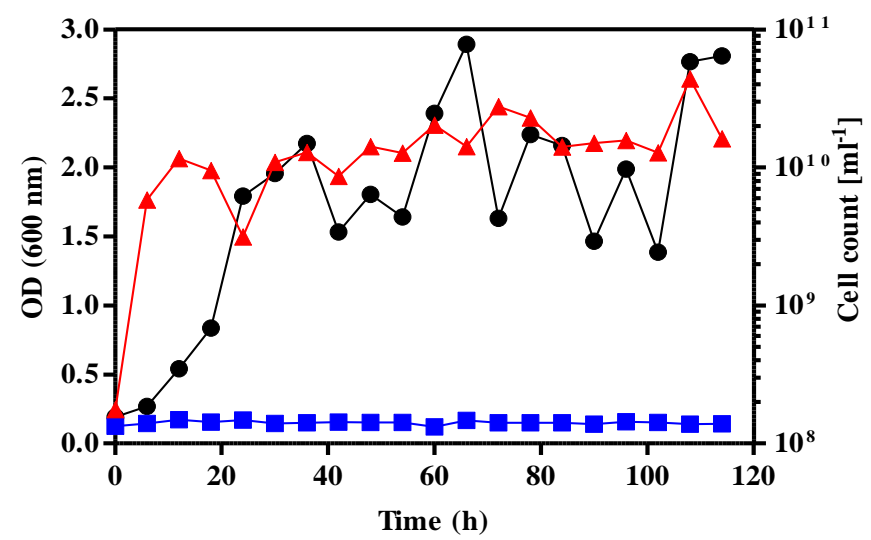

Figure 11 Growth of Pantoea cypripedii strain EO2 with $2.5 \mathrm{mM}$ tannic acid as sole source of carbon and energy. Growth parameters $\left(\mathrm{OD}_{600}=\bullet\right.$, cell count $\left.=\boldsymbol{\Delta}\right)$ plotted against time together with control in the absence of tannic acid $\left(\mathrm{OD}_{600}=\right.$ घ).

Differences in lag periods were observed as the concentration of tannic acid (TA) in the medium was increased. For strain EO1, growth in $0.25 \mathrm{~g} \mathrm{~L}^{-1} \mathrm{TA}$ was preceded by a lag period of about $18 \mathrm{~h}$, whereas strain EO2 grew with mean lag phase of $12 \mathrm{~h}$ for same TA concentration and $6 \mathrm{~h}$ for TA concentrations of 1,2 , 2.5 and $5 \mathrm{~g} \mathrm{~L}^{-1}$ respectively. Inoculation of fresh medium containing $1 \mathrm{~g} \mathrm{~L}^{-1} \mathrm{TA}$ with overnight TA cultures of strain EO2 decreased the lag time, although there was no change in the maximum tolerable level of tannin. No lag phase was observed at different concentrations of gallic acid in cultures of strains EO1 (Figure 8) and EO2 (Figure 9) respectively.

The utilization of tannic acid by the strains was also demonstrated using the spectrophotometric analysis of residual tannic acid in the medium after $24 \mathrm{~h}$ growth of the isolates. Incubation of medium in the absence of cells as control under the same conditions showed that a small part of tannic acid also underwent autoxidation and formed a precipitate. Strain EO2 showed appreciable utilization of tannic acid (about 42\%) while strain EO1 showed about $30 \%$ utilization of tannic acid after $24 \mathrm{~h}$ of growth. This is shown in Figure 12.

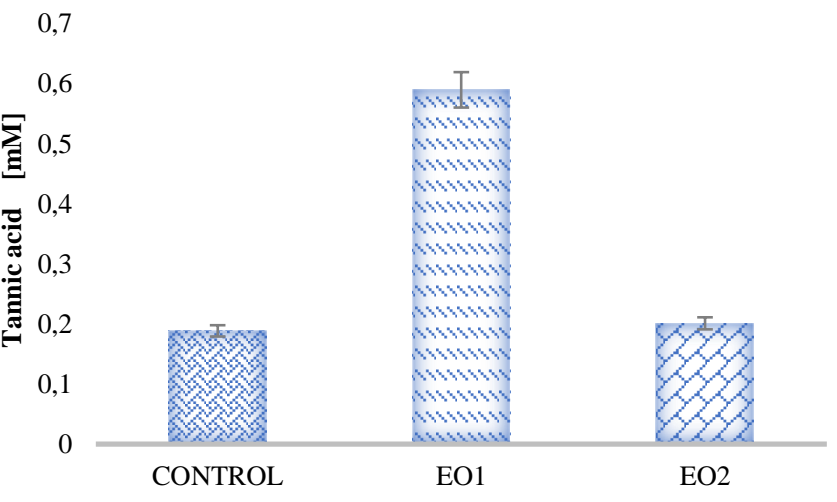

Figure 12 Utilization of tannic acid by the strains estimated in terms of residua tannic acid (mM) after $24 \mathrm{~h}$ of growth.

\section{Carbon source assimilation}

Strains EO1 and EO2 were able to utilize tannic acid, gallic acid, glucose succinate, benzoic acid and protocatechuic acid but not catechol or $\beta$. hydroxybenzoic acid. However, strain EO2 utilized benzoic acid by $74.44 \%$, while strain EO1 only by $22.95 \%$ at $24 \mathrm{~h}$ of growth. The fact that none of the strains utilized catechol or $\mathrm{p}$-hydroxybenzoic acid, indicating that neither acted as intermediate in the pathway of degradation of tannic acid/gallic acid. Gallotannin (tannic acid) degradation products, namely glucose and gallic acid and pyrogallo were detected in the culture filtrates of these microorganisms by TLC (not shown) and GC-MS (Figure 13) respectively.
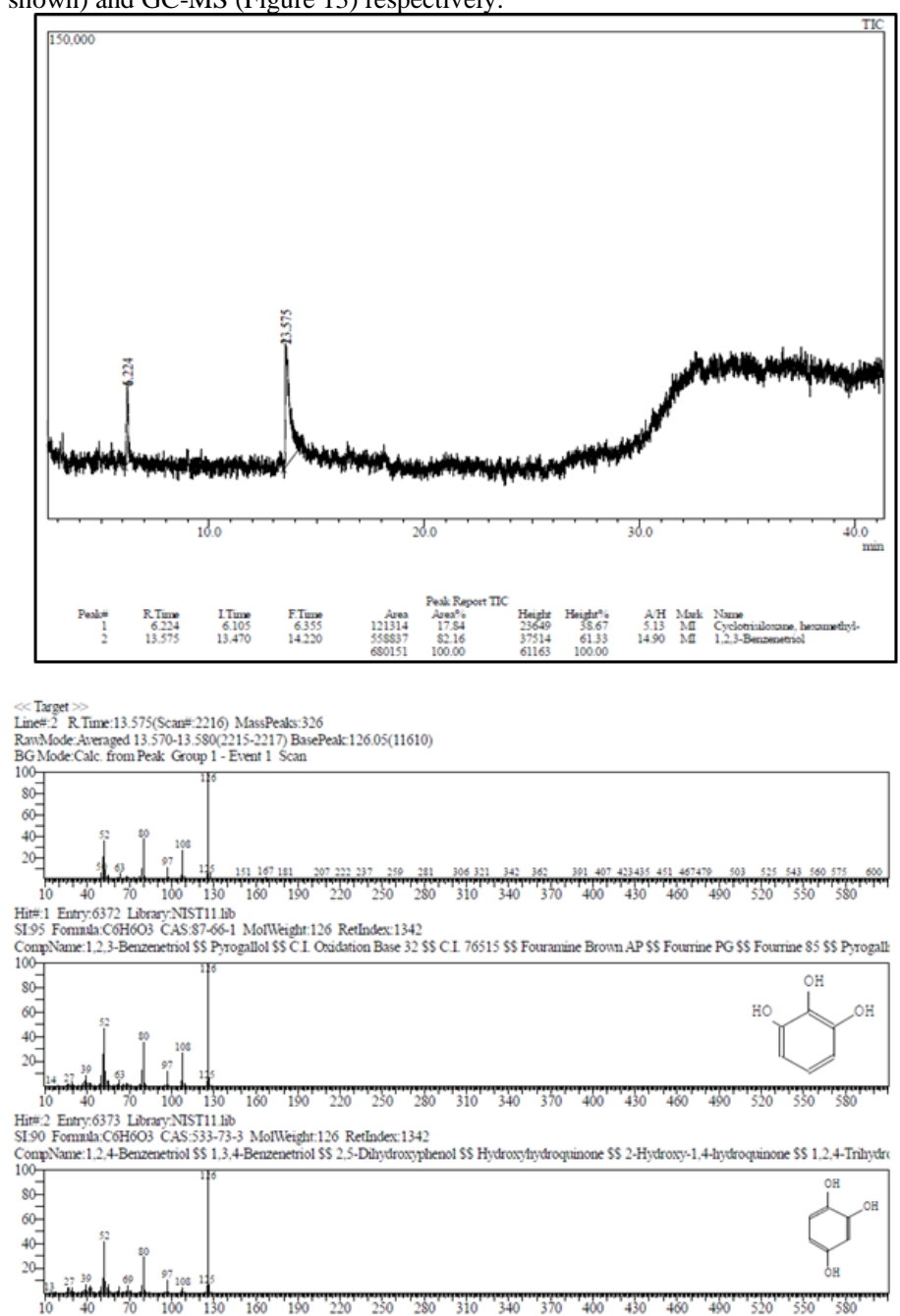

Figure $13 \mathrm{GC} / \mathrm{MS}$ detection of the metabolite benzene-1,2,3-triol (Pyrogallol) formed by the strains EO1 and EO2 during tannin degradation

\section{Enzymatic activity for tannic acid hydrolysis}

Tannase activity was detected in strains EO1 and EO2 grown on tannic acid Visual evaluation of the enzymatic tests showed positive results for both strains 
as confirmed by the visible colour change in media from green to brown on exposure to atmosphere (Table 1). The activity of both strains was clearly higher

than that of the control.

Table 1 Spectrophotometric detection of tannase activity

\begin{tabular}{lll}
\hline Bacterial strains & Tannase activity $\left(\mathrm{Abs}_{440 \mathrm{~nm}}\right)$ & Colour change from green to brown
\end{tabular}

Klebsiella pneumoniae $\mathrm{EO} 1$

Pantoea cypripedii EO2

Control
$0.060 \pm 0.002$

$0.069 \pm 0.003$

$0.022 \pm 0.005$

Data are mean of triplicate measurements \pm standard deviations

\section{DISCUSSION}

Tannins (condensed or hydrolyzable) have a superfluity of hydroxyl groups to constitute hydrogen bonds with proteins and amino acids and to form complexes with metals. They are well known to hold strongly to proteins in vitro and form tannin-protein complexes (T-PC), which are quite resistant to degradation by enzymes (Chowdhury et al., 2004). This enabling power to complex with proteins and amino acids causes the inhibition of organic matter degradation in the environment. Besides complexing bacterial or fungal exoenzymes and directly slowing down biodegradation, tannins can also sequestrate particular type of nitrogen sources that are used by bacteria with tannins as substrate for their growth (Jadhav et al., 2011). The discharged of residual tannins associated with sawmill wastes into the Lagos lagoon water may therefore have detrimental effects on living organisms, which eventually can result to serious pollution of the environment (Chowdhury et al., 2004). Notwithstanding the fact that tanninutilizing microorganisms that use tannins as carbon and energy sources had been isolated by several authors (Bhat et al., 1998; Franco et al., 2005; Pepi et al., 2010).

The two bacterial isolates used in this study (designated as strains EO1 and EO2) were selected due to their tannin degrading capabilities and apparent tannase and gallic acid decarboxylase (GAD) activities. These strains produced clear halo zones on agar plates containing tannic acid and black blue colouration with $1 \%$ $\mathrm{FeCl}_{3}$ solution after growth with gallic acid which are considered indicators for tannase and GAD producers (Sharma et al., 2000; Osawa et al., 2006; Murugan et al., 2007; Sariozlu and Kivanc, 2009). The isolation and characterization of tannic acid degrading species of Klebsiella and Pantoea were similarly reported by other authors (Jadhav et al., 2011; Chávez-González et al., 2012). Furthermore, a mesophilic bacterium designated M24 that degraded $83 \%$ tannic acid in 5 days was also isolated (Jadhav et al., 2011). Tannins utilization by Escherichia coli, Azotobacter vinelandii, and Pseudomonas fluorescens as sole carbon source was reported by Basaraba (1966), while Deschamps et al. (1983) reported the degradation of $1 \%\left(\mathrm{w} \mathrm{v}^{-1}\right)$ gallotannin by Corynebacterium sp., Bacillus polymyxa, Bacillus pumilus, and Klebsiella pneumoniae. A maximum of $1 \%$ tannic acid was utilized by $K$. pneumoniae (Mingshu et al., 2006). Bacterial strains of the genus Pantoea were previously isolated from fecal material, plants and soil (Andersson et al., 1999), because of their nature as either pathogens or commensals (Pepi et al., 2010). However, so far the utilization of tannic acid by members of this genus was not reported. Both Klebsiella pneumoniae strain EO1 and Pantoea cypripedii strain EO2 isolated in the present study grew in minimal media containing tannic acid at a concentration above $10 \mathrm{~g} \mathrm{~L}^{-1}$. Hence, they can tolerate higher concentrations of tannic acid (25 $\mathrm{g} \mathrm{L}^{-1}$ ), which is an advantage in highly polluted environments and a unique feature of these two strains.

Growth studies illustrated that the bacterial strains (Klebsiella pneumoniae and Pantoea cypripedii) were initially inhibited by the presence of tannic acid in the media indicated by an extended lag phase of $18 \mathrm{~h}$ for EO1 and $12 \mathrm{~h}$ for EO2 strains at a concentration of $0.25 \mathrm{~g} \mathrm{~L}^{-1}$. The lag phase for strain $\mathrm{EO} 2$ was decreased to about $6 \mathrm{~h}$ at a tannic acid concentration of $1 \mathrm{~g} \mathrm{~L}^{-1}$ while strain EO1 showed no lag phase at this concentration. Similarly, the cell counts demonstrated that strain EO1 but not EO2 was slightly inhibited by the presence of tannin $(2.5 \mathrm{mM})$ in the medium. These data indicated that at high tannin concentrations, both strains were inhibited and that adaptation by metabolic transformation or enzyme induction of the tannin molecule is needful. The fact that the tannin-concentration dependent of the lag period indicates that growth in the presence of tannins may be at least partly dependent on the metabolic transformation of the tannin molecule to less toxic intermediates as no lag phases were evident at the tested concentrations of gallic acid in growth experiments of strains EO1 and EO2. However, resistance to tannins was less likely to be due to acid hydrolysis of tannin-protein complexes. A reduction in or disappearance of the lag period after re-inoculation of tannin-grown strains EO1 and EO2 supports the view that adaptation is associated with a time-dependent event such as enzyme induction.

The bacterial strains isolated in this work showed tannase activity. Although tannase activity has been widely reported in plants and animals, microorganisms (bacteria, yeasts, and fungi) typically show the highest activity of tannase
(Aguilar et al., 2007). The two strains EO1 and EO2 showed tannase activities similar to those reported for other bacterial strains isolated from food related materials (Vaquero et al., 2004). Evidence of tannase activity was also reported by Osawa and Walsh (1993) for Enterobacteriaceae and Streptococcus bovis isolated from feces of koalas. Additionally, Klebsiella planticola and Klebsiella pneumoniae (Deschamps et al., 1983) as well as Enterococcus faecalis (Goel et al., 2005) were reported as tannase producers.

Based on the 16S rRNA gene sequence similarity and phylogenetic analysis, strains EO1 and EO2 were assigned to the genera Klebsiella and Pantoea. Klebsiella species with the ability of tannic acid degradation were previously isolated from garden soil (Jadhav et al., 2011), from tannery effluent in the presence of tannic acid (Sivashanmugam and Jayaraman, 2011), from oil mil wastes (Pepi et al., 2013), and from goat feces (Tahmourespour et al., 2016). The hydrolysis of tannic acid was confirmed by the detection of tannase activity and the hydrolysis products, gallic acid and glucose, as previously shown by Mingshu et al. (2006) in cultures of three bacterial strains. The gallic acid can be decarboxylated by gallate decarboxylase to yield pyrogallol, as was demonstrated in a number of bacterial species (Krumholz and Bryant, 1986; Brune and Schink, 1992). In fact, Deschamps et al. $(1980,1983)$ grew strains of Klebsiella pneumoniae and $K$. planticola on tannins, which utilized gallic acid as a carbon source.

The two isolates obtained in this study brought about the aerobic utilization of tannic acid giving rise to pyrogallol with a proposed metabolic scheme (Figure 14), which was observed in the bacterial catabolism of tannic acid previously (Kumar et al., 1999; Mingshu et al., 2006). The possible product of orthocleavage of pyrogallol is 2-hydroxymuconic acid (Kumar et al., 1999), which could undergo further catabolism to form pyruvate and acetaldehyde. These two microorganisms could therefore be potentially used for the treatment of tanninrich polluted environments. The strains (EO1 and EO2) might also be a promising source for the enzymes tannase (Lekha and Lonsane, 1997) and gallate decarboxylase (Zeida, 1998), which have widespread applications in food processing, brewing, pharmaceuticals, medicine, textiles and detergents industries.

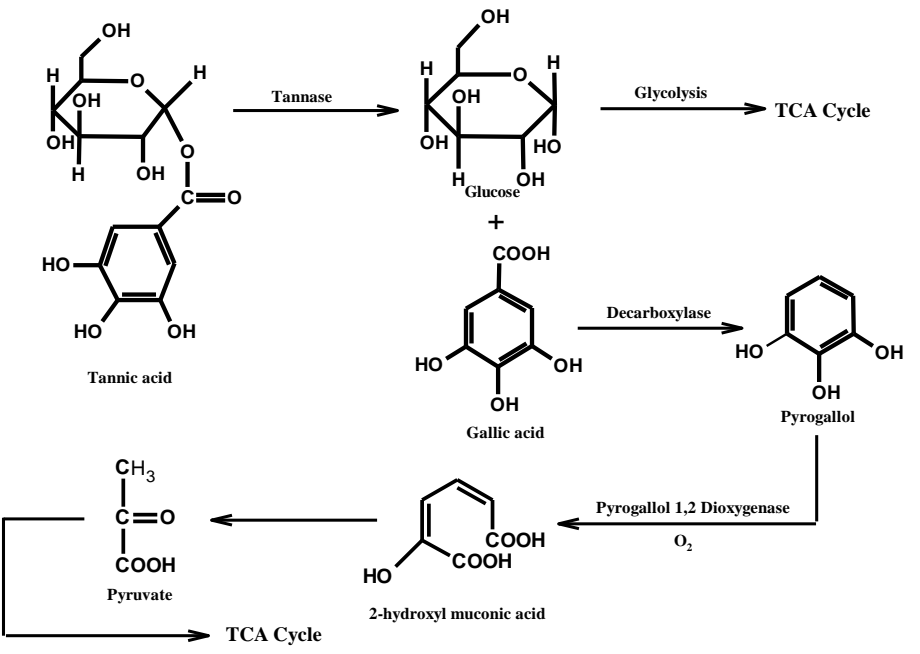

Figure 14 Proposed catabolic routes of tannic acid degradation by Klebsiella pneumoniae strain EO1 and Pantoea cypripedii strain EO2

\section{CONCLUSION}

The taxonomic profiles of tannic acid-degrading bacteria obtained in this study indicated that they are members of the genera Klebsiella and Pantoea. These new isolates could positively contribute to the elimination of polyphenolic pollutants in the estuarine and soil environments of their origin. 
Acknowledgements: The lead author acknowledges Dr. Abayomi, Chemistry Department, University of Lagos, in helping out for structural pathway.

\section{REFERENCES}

AGUILAR, C.N., AUGUR, C., FAVELA-TORRES, E., VINIEGRAGONZÁLEZ, G. 2001a. Induction and repression patterns of fungal tannase in solid-state and submerged cultures. Process Biochemistry, 36, 565-570.

AGUILAR, C.N., GUTI'ERREZ-S'ANCHEZ, G. 2001. Review sources, properties, applications and potential uses of tannin acyl hydrolase. Food Science and Technology International, 7, 373- 382

AGUILAR, C.N., RODR'IGUEZ, R., GUTIERREZ-SANCHEZ, G., AUGUR, C., FAVELA-TORRES, E., PRADO- BARRAG'AN, L.A., RAM'IREZ CORONEL, A., CONTRERAS-ESQUIVEL, J.C. 2007. Microbial Tannases Advances and Perspectives. Applied Microbiology and Biotechnology, 76, 47-59. ANDERSSON, A.M., WEISS, N., RAINEY, F., SALKINOJA-SALONEN, M.S 1999. Dust-borne bacteria in animal sheds, schools and children's day care centres. Journal of Applied Microbiology, 86, 622 - 634.

BAJPAI, B., PATIL, S.A. 2008. New approach to microbial production of gallic acid. Brazilian journal of microbiology, 39, 708-711.

BASARABA, J. 1966. Effects of vegetable tannins on glucose oxidation by various microorganisms. Canadian Journal of Microbiology, 12, 787-794.

BELMARES, R., CONTRERAS-ESQUIVEL, J.C., RODRÍGUEZ-HERRERA, R., RAMÍREZ CORONEL, A., AGUILAR, C.N. 2004. Microbial production of tannase: an enzyme with potential use in food industry. Lebensm Wis Technology, 37, 857-864.

BHAT, T.K., SINGH, B., SHARMA, O.P. 1998. Microbial degradation of tannins - a current perspective. Biodegradation, 9, 343-357.

BROOKER, J.D., O'DONOVAN, L., SKENE, I., SELLICK, G. 1999 Mechanism of tannin resistance and detoxificationin the rumen microbia biosystems. In: Bell, C.R., Brylinsky, M., Johnson, G., (Eds.), New Fronties Proceedings of the Eighth International Symposium of Microbial Ecology, Atlantic Canada Society for Microbial Ecology Halifax, Canada, pp. 1-9.

BRUNE, A., SCHINK, B. 1992. Phloroglucinol pathway in the strictly an aerobic Pelobacter acidigallici: fermentation of trihydroxybenzenes to acetate via triacetic acid. Archives of Microbiology, 157, 417-424.

BURAIMOH, O.M., AMUND, O.O., ILORI, M.O. 2015. Kraft lignin degradation by autochtonous Streptomyces strains isolated from a tropical lagoon ecosystem. Journal of Microbiology, Biotechology and Food Sciences, 5 (3), 248-253. https://dx.doi.org/10.15414/jmbfs.2015/16.5.3.248-253

CHÁVEZ-GONZÁLEZ, M., RODRÍGUEZ-DURÁN, L.V., BALAGURUSAMY, N., PRADO-BARRAGÁN, A., RODRÍGUEZ, R., CONTRERAS, J.C., AGUILAR, C.N. 2012. Biotechnological Advances and Challenges of Tannase: An Overview. Food and Bioprocess Technology, 5 (2), 445-459. https://dx.doi.org/10.1007/s11947-011-0608-5

CHANG, K.T., WEI, C.I., JOHNSON, G.M. 1998. Are tannins a double-edged sword in biology and health? Trends in Food Science and Technology, 9, 168 175

CHOWDHURY, S.P., KHANNA, S., VERMA, S.C., TRIPATHI, A.K. 2004 Molecular diversity of tannic acid degrading bacteria isolated from tannery soil. Journal of Applied Microbiology, 97, 1210-1219. http://dx.doi.org/10.1111/j.1365-2672.2004.02426.x

CLIFFORD, M.N., SCALBERT, A. 2000. Review: Ellagitannins-nature, occurrence and dietary burden. Journal of the Science of Food and Agriculture $80,1118-1125$.

DAS MOHAPATRA, P.K., MONDAL, K.C., PATI, B.R. 2007. Production of tannase by the immobilized cells of Bacillus licheniformis KBR6 in Ca-aliginate beads. Journal of Applied Microbiology, 102, 1462-1467.

DESCHAMPS, A.M., MAHOUDEAU, G., CONTI, M., LEBEAULT, J.M. 1980 Bacteria degrading tannic acid and related compounds. Journal of Fermentation Technology, 58, 93-97.

DESCHAMP, A.M., OTUK, G., LEBEAULT, J.M. 1983. Production of tannase and degradation of chestnut tannins by bacteria. Journal of Fermentation Technology, 61 (1), 55-59.

FRANCO, A.R., CALHEIROS, C.S.C., PACHECO, C.C., DE MARCO, P., MANAIA, C.M., CASTRO, P.M.L. 2005. Isolation and characterization of polymeric galloyl-ester-degrdaing bacteria from a tannery discharge place. Microbial Ecology, 50, 550-556.

GOEL, G., PUNIYA, A.K., AGUILAR, C.N., SINGH, K. 2005. Interaction of gut microflora with tannins in feeds. Naturwissenschaften, 92, $497-503$.

HAGERMAN, A.E., BUTLER, L.G. 1978. Protein Precipitation Method for Quantitative Determination of Tannins. Journal of Agricultural and Food Chemistry, 26, 809-812.

HOLT, J.G., KRIEG, N.R., SNEATH, P.H.A., STALEY, J.T., WILLIAMS, S.T. 1994. Bergey's Manual of Determinative Bacteriology, ninth ed. Williams and Wilkins, United States of America

JADHAV, U., KADU, S., THOKAL. N., PADUL, M., DAWKAR, V., CHOUGALE, A., SALVE, A., PATIL, M. 2011. Degradation of tannic acid by cold-adapted Klebsiella sp. NACASA1 and phytotoxicity assessment of tannic acid and its degradation products. Environmental Science and Pollution Research, 18, 1129-1138.

KAR, B., BANERJEE, R., BHATTACHARYYA, B.C. 1999. Microbial production of gallic acid modified solid state fermentation. Journal of Industrial Microbiology and Biotechnology, 23, 173-177.

KRUMHOLZ, L.R., BRYANT, M.P. 1986. Eubacterium oxidoreducents sp. nov. requiring $\mathrm{H}_{2}$ or formate to degrade gallate, pyrogallol, phloroglucinol and quercetin. Archives of Microbiology, 14, 8-14.

KUMAR, R.A., GUNASEKARAN, P., LAKSHMANAN, M. 1999. Biodegradation of tannic acid by Citrobacter freundii isolated from a tannery effluent. Journal of Basic Microbiology, 39, 161-168.

KUMAR, S., STECHER, G., LI, M., KNYAZ, C., TAMURA, K. (2018). Mega $\mathrm{X}$ : Molecular Evolutionary Genetics Analysis across computing platforms Molecular Biology and Evolution, 35, 1547-1549.

LEAHY, J.G., COLWELL, R.R. 1990. Microbial degradation of hydrocarbons in the environment. Microbiological Reviews, 54, 305-315.

LEKHA, P.K., LONSANE, B.K. 1997. Production and application of tannin acyl hydrolase: State of the art. Advances in Applied Microbiology, 44, 215-260.

LEWIS, J.A., STARKEY, R.L. 1969. Decomposition of plant tannins by some soil microorganisms. Soil Science, 107, 235-241.

LOWRY, J.B., MCSWEENEY, C.S., PALMER, B. 1996. Changing perceptions of the effect of plant phenolics on nutrient supply in ruminant. Australian Journal of Agricultural Research, 47, 829 - 842.

MINGSHU, L., KAI, Y., QIANG, H., DONGYING, J. 2006. Biodegradation of gallotannins and ellagitannins. Journal of Basic Microbiology, 46, 68-84

MOHAMMED, Y.H.I. 2016. Isolation and characterization of tannic acid hydrolysing bacteria from soil. Biochemistry and Analytical Biochemistry, 5 (1), 1-6. https://dx.doi.org/10.4172/2161-1009.1000254

MOHAPATRA, P.K.D., MAITY, C., RAO, R.S., PATI, B.R., MONDAL, K.C 2009. Tannase production by Bacillus licheniformis KBR6: Optimization of submerged culture conditions by Taguchi DOE methodology. Food Research International, 42 (4), 430-435. http://dx.doi.org/10.1016/j.foodres.2009.02.013

MONDAL, K.C., BANERJEE, D., JANA, M., PATI, B.R. 2001. Colorimetric assay method for determination of the tannin acyl hydrolase activity. Analytical Biochemistry, 295, 168-171.

MOXLEY, K., SCHMIDT, S. 2012. Isolation of a phenol-utilizing marine bacterium from Durban Harbour (South Africa) and its preliminary characterization as Marinobacter sp. KM2. Water Science and Technology, 65 (5), 932-939. http://dx.doi.org/10.2166/wst.2012.940

MUKHERJEE, G., BANERJEE, R. 2006. Effects of temperature, $\mathrm{pH}$ and additives on the activity of tannase produced by a co-culture of Rhizopus oryzae and Aspergillus foetidus. World Journal of Microbiology and Biotechnology, 22, 207-211.

MURUGAN, K., SARAVANABABU, S., ARUNACHALAM, M. 2007. Screening of tannin acyl hydrolase (E.C.3.1.1.20) producing tannery effluent fungal isolates using simple agar plate and $\mathrm{SmF}$ process. Bioresource Technology, 98, 946-949.

OSAWA, R., WALSH, T.P. 1993. Visual reading method for detection of bacterial tannase. Applied and Environmental Microbiology, 59, 1251-1252.

OSAWA, R., FUJISAWA, T., PUKALL, R. 2006. Lactobacillus apodemi sp. Nov., a tannase-producing species isolated from wild mouse faeces. International Journal of Systematic and Evolutionary Microbiology, 56 (7), 1693-1696. http://dx.doi.org/10.1099/ijs.0.64147-0

PELL, A.N., WOOLSTON, T.K., NELSON, K.E., SCHOFIELD, P. 2000 Tannins: biological activity and bacterial tolerance. In: Tannins in livestock and human nutrition. Brooker, J.D., (ed.), Proceedings of an international workshop, Agricultural Research, Adelaide, Australia, pp. 121-126.

PEPI, M., LAMPARIELLO, L.R., ALTIERI, R., ESPOSITO, A., PERRA, G., RENZI, M., LOBIANCO, A., FEOLA, A., GASPERINI, S., FOCARDI, S.E 2010. Tannic acid degradation by bacterial strains Serratia spp. and Pantoea sp. isolated from olive mill waste mixtures. International Biodeterioration and Biodegradation, 64, 73- 80 .

PEPI, M., CAPPELLI, S., HACHICHO, N., PERRA, G., RENZI, M. TARABELLI, A., ALTIERI, R., ESPOSITO, A., FOCARDI, S.E., HEIPIEPER H.J. 2013. Klebsiella sp. strain C2A isolated from olive oil mill waste is able to tolerate and degrade tannic acid in very high concentrations. FEMS Microbiology Letters, 343, 105-112. http://dx.doi.org/10.1111/1574-6968.12136

PINTO, G., LEITE, S., TARZI, S., COURI, S. 2001. Selection of tannase producing Aspergillus niger strains. Brazilian Journal of Microbiology, 32, 24

POURRAT, H., REgERAT, F., MORVAN, P., POURRAT, A. 1987. Microbiological production of gallic acid from Rhus coriaria. L. Biotechnology Letters, 9, 731-734.

REED, J.D. 1995. Nutritional toxicology of tannins and related polyphenols in forage legumes. Journal of Animal Science, 73, 1516-1528.

SAITOU, N., NEI, M. 1987. The neighbor-joining method: A new method for reconstructing phylogenetic trees. Molecular Biology and Evolution, 4, 406-425. SARIÖZLÜ, N.Y., KIVANÇ, M. 2009. Isolation of gallic acid-producing microorganisms and their use in the production of gallic acid from gall nuts and sumac. African Journal of Biotechnology, 8, 1110-1115. 
SCALBERT, A. 1991. Antimicrobial properties of tannins. Phytochemistry, 30, 3875-3883.

SCHMIDT, S., FORTNAGEL, P. 1998. Catabolism of 4-hydroxy- and 4,40 dihydroxydiphenyl ether by Sphingomonas sp. strain SS3 leads to the production of a toxic metabolite. Microbiological Research, 153, 331-335.

SETH, M., CHAND, S. 2000. Biosynthesis of tannase and hydrolysis of tannins to gallic acid by Aspergillus awamori - Optimization of process parameters. Process Biochemistry, 36, 39-44.

SHARMA, S., BHAT, T.K., DAWRA, R.K. 2000. A spectrophotometric method for assay of tannase using rhodanine. Analytical Biochemistry, 279, 85-89.

SINGH, H.P., RAVINDRANATH, S.D., SINGH, C. 1999. Analysis of tea shoot catechins: spectrophotometric quantitation and selective visualization on twodimensional paper chromatograms using diazotized sulphanilamide. Journal of Agricultural and Food Chemistry, 47 (3), 1041-1045.

SIVASHANMUGAM, K., JAYARAMAN, G. 2011. Production and partial purification of extracellular tannase by Klebsiella pneumoniae MTCC 7162 isolated from tannery effluent. African Journal of Biotechnology, 10 (8), 13641374. http://dx.doi.org/10.5897/AJB10.1209

SIVASHANMUGAM, K., JAYARAMAN, G. 2011. Media optimization for extra cellular tannase production by Klebsiella pneumoniae MTCC 7162 using response surface methodology. African Journal of Microbiology Research, 5 (22), 3611-3615. http://dx.doi.org/10.5897/ajmr10.774

SUPRANO, O. 2005. Phenolic reactions for leather tanning and dyeing, PhD thesis, University of Leicester, United Kingdom.

TAHMOURESPOUR, A., TABATABAEE, N., KHALKHALI, H., AMINI, I. 2016. Tannic acid degradation by Klebsiella strains isolated from goat feces Iranian Journal of Microbiology, 8 (1), 14-20.

TREVIÑO-CUETO, B., LUIS, M., CONTRERAS-ESQUIVEL, J.C. RODRÍGUEZ, R., AGUILERA, A., AGUILAR, C.N. 2007. Gallic acid and tannase accumulation during fungal solid state culture of a tannin-rich desert plant (Larrea tridentate Cov). Bioresource Technology, 98, 721-724.

VAN HAMME, J.D., SINGH, A., WARD, O.P. 2003. Recent Advances in Petroleum Microbiology. Microbiology and Molecular Biology Reviews, 67 (4), 503-549. https://dx.doi.org/10.1128/mmbr.67.4.503-549.2003

VAN SOEST, P.J. 1994. Nutritional Ecology of the Ruminant. Ithaca, New York. VAQUERO, I., MARCOBAL, A., MU NOZ, R. 2004. Tannase activity by lactic acid bacteria isolated from grape must and wine. International Journal of Food $\begin{array}{llllll}\text { Microbiology, } & 96 & \text { (2), } & 199 & - & 204\end{array}$ http://dx.doi.org/10.1016/j.ijfoodmicro.2004.04.004

ZEIDA, M., WIESER, M., YOSHIDA, T., SUGIO, T., NAGASAWA, T. 1998. Purification and characterization of gallic acid decarboxylase from Pantoea agglomerans T71. Applied Environmental Microbiology, 64, 4743 - 4747. 


\section{SUPPLEMENTARY INFORMATIONS}

\section{Appendices}

The optimum absorbency of tannic acid with resulting calibration curve of tannic acid in minimal salts medium at $278 \mathrm{~nm}$ was demonstrated (Figure A.1). The linear range of the curve was $0.0004-0.04 \mathrm{mM}\left(\mathrm{r}^{2}=0.99\right)$

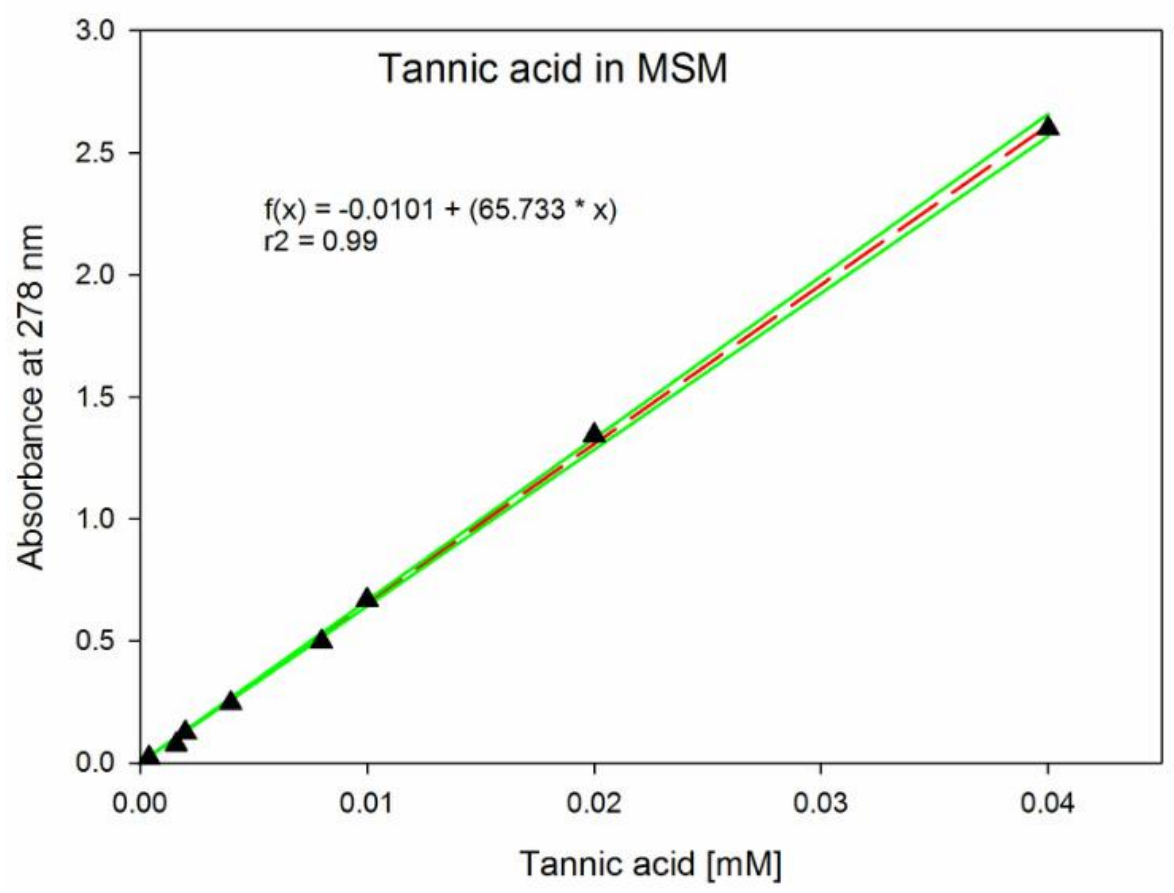

Figure A.1 The resulting calibration curve of tannic acid standard in Minimal Salts Medium at $278 \mathrm{~nm}$

$\Delta$

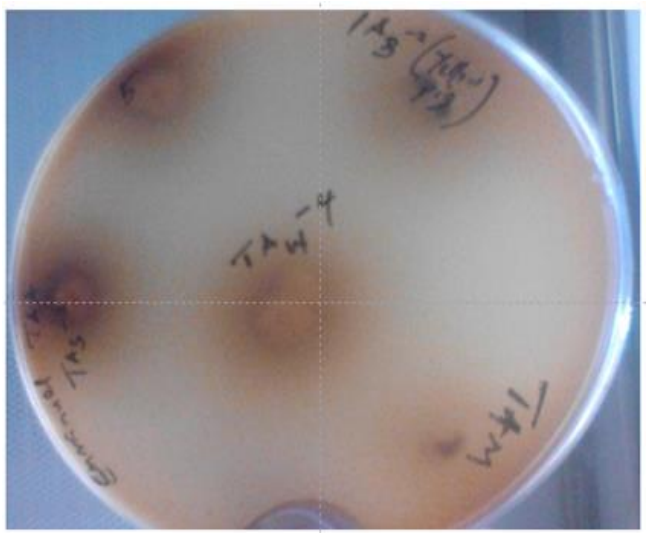

B

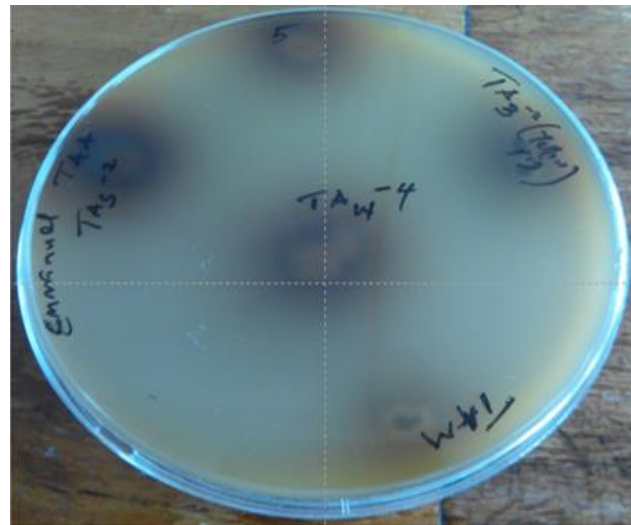

C

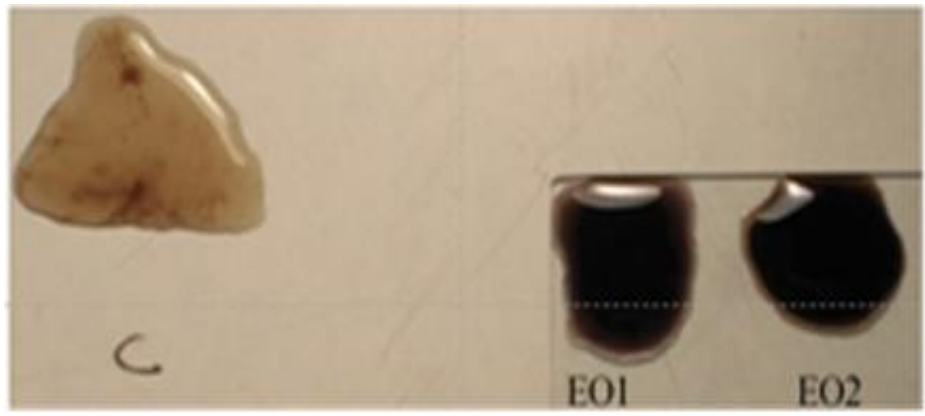

Figure B.1 TA agar plate screening for tannase/GAD producing bacteria: Klebsiella pneumoniae strain EO1 (A) and Pantoea cypripedii strain EO2 (B) showing zone of clearance indicating tannic acid utilization. Strains EO1 and EO2 showing blue-black colour reactions indicating gallic acid utilization (C), the inserted C, control (without bacterial cells). 